\title{
OVERVIEW OF MUCOADHESIVE BIOPOLYMERS FOR BUCCAL DRUG DELIVERY SYSTEMS
}

\author{
VIVEK PURI, AMEYA SHARMA, PARAMJOT MAMAN, NISHANT RATHORE, INDERBIR SINGH ${ }^{*}$
}

Chitkara College of Pharmacy, Chitkara University, Punjab, India

Email: inderbir.singh@chitkara.edu.in

Received: 16 Aug 2019, Revised and Accepted: 10 Oct 2019

\begin{abstract}
Mucoadhesive dosage forms may be intended for facilitation of prolonged retention time at the application site hence providing drug release in a controlled rate for enhanced improvement of therapeutic activity and its outcome. The buccal mucosa has been investigated for systemic drug delivery and local drug treatment or therapy that is subjected to first pass metabolism. The applicability of bio-adhesion approach in buccal drug delivery proved great therapeutic potential to overcome the limitation of conventional buccal drug delivery. The delivery via buccal route using mucoadhesive biopolymers such as various natural gums e.g. carrageenans, gum karaya, gum arabic, locust bean gum, khaya gum, gum ghatti, albizia gum, guar gum, starch, cellulose, larch gum and pectin etc. and various thiolated and carboxymethylated polymers has been the subject of interest since the early $20^{\text {th }}$ century. The present article is focused mainly on the oral mucosa, mechanism of drug permeation, and characteristics of the desired polymers, the manuscript then proceeds to cover the theories behind the adhesion of bioadhesive polymers to the mucosal epithelium followed by the factors affecting mucoadhesion. Further the author has also discussed on the new generation of mucoadhesive polymers and their properties, recent mucoadhesive formulations for enhanced buccal drug delivery, various marketed products and patent literature. Various online search engines and scientific journals were employed for the collection of literature and scientific data and information related to the topic using keywords like mucoadhesive polymers, buccal drug delivery, buccal patches, tablets, films, gels, powder from the year 2002 and above.
\end{abstract}

Keywords: Buccal, Films, Gums, Patches, Therapeutic efficacy, Thiolation

(C) 2019 The Authors. Published by Innovare Academic Sciences Pvt Ltd. This is an open access article under the CC BY license (http://creativecommons.org/licenses/by/4.0/) DOI: http://dx.doi.org/10.22159/ijap.2019v11i6.35438

\section{INTRODUCTION}

Mucoadhesion or mucosal adhesion is defined as the state which is responsible for the adhesion between two materials for a definite material of time. With the help of interfacial forces between two materials, the adhesion occurs and the phenomenon known as bioadhesion (biologically adherence between two materials, when one of the material is biological in nature) [1]. The mucoadhesion was first introduced in 1980's for delivering the drug in controlled manner and providing the ease of controlled drug delivery. This concept of mucoadhesion is a new approach for the improvement of drug efficacy for various drug delivery systems. In systemic delivery the formulation is kept for intimate contact with tissue or cells at the site of absorption. In nasal, vaginal and local drug delivery it is carried out by spatial placement within gastrointestinal tract (absorption site is in gastro region) [2]. Over the last two decades mucoadhesion has become an area of interest for the administration of various unstable bioactive via different route of administration (nasal, vaginal, ocular and buccal which are generally difficult to administer by oral route). Mucoadhesive material can also be used as therapeutic agent as it coat and protects the damaged tissues or act as lubrication agents. Mucoadhesion is due to formation of noncovalent bonds such as hydrogen bonds and ionic interactions or physical entanglements between the mucus gel layer and polymer. Additionally, the residence time of dosage form in the Gastro intestinal mucosa should be prolonged, which allows a constant drug release at a given aim site to maximize the therapeutic effect [3]. There are many factors that depend on mucoadhesion as shown in (fig. 1)

The oral cavity is a preferred site for the transmucosal delivery of drugs. Buccal route offers advantages like avoidance of first pass metabolism and gastrointestinal degradation of drugs, high blood flow which ensures systemic drug bioavailability [4]. Various buccal bioadhesive polymers are available for ascertaining adhesive contact with the buccal mucosa thereby increasing the buccal residence time of the delivery system for optimal drug bioavailability. Some properties of the polymers affecting bioadhesive potential includes, number of hydrogen bonding groups, charge, molecular weight, chain flexibility, and surface energy properties [5]. A range of natural and synthetic polymers are available for developing different bioadhesive drug delivery systems.

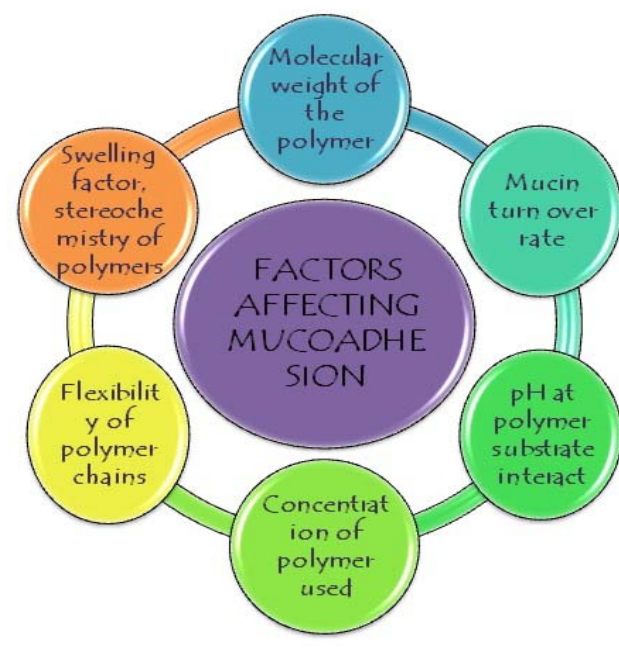

Fig. 1: Different factors affecting the process of mucoadhesion

Approaches/theories of mucoadhesion

\section{Wetting theory}

The wetting theory is generally applied in mucoadhesive system (liquid) having low viscosity. The theory postulates about the mucoadhesive polymer ability that easily spreads on biological surface which leads to the extensively spreading ability of active drug delivery systems. This theory describes that the adhesive constituent penetrates in irregularities in surface which hardens and get attached to the surfaces because of drastic changes occurs in surfaces and interfacial energies [2]. The adhesive mechanism of such elastoviscous liquid may be defined by using wettability and spreadability as shown in (fig. 2). The contact angle techniques are based on the principle that lowers the contact angle, these are used to determine the affinity of a liquid to measure contact angle of the liquid on the surface. The theory postulates that the lower the contact angle, the greater will be the affinity of liquid to the solid surface [6]. 


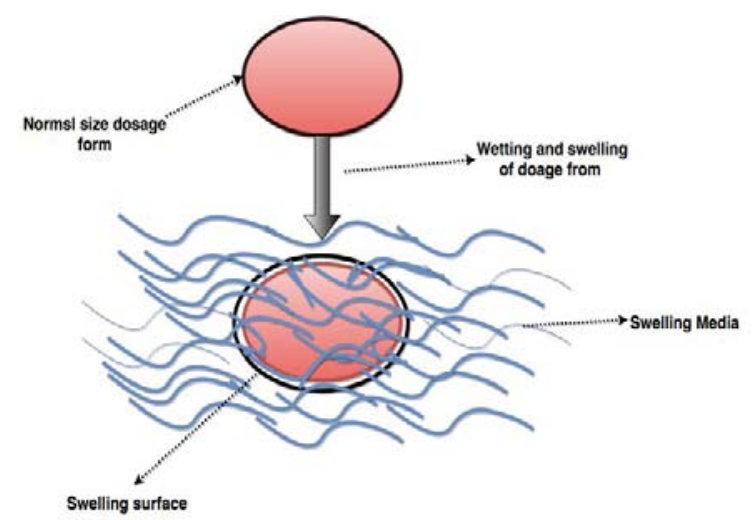

Fig. 2: Shows penetration of dosage form into the surface or tissue of the mucosal layer by wetting or swelling mechanism

\section{Adsorption theory}

Adhesion is defined as the result of interactions in various surfaces (primary and secondary) are two types of chemical bonds for adhesive interactions i. e hydrogen bond and Vandar waals' forces are deep-rooted between the adhesive polymer and mucus substrate which is depicted in (fig. 3). Primary bonds occurs due to the chemisorptions which results in adhesion due to ionic, covalent and metallic bonding, while the secondary bonds arises mainly due to Vander waals forces, hydrophobic interactions and hydrogen bonding [7].

\section{Electronic theory}

This theory tells that the adhesion occurs due to electron transfer between the mucus and the mucoadhesive system which is arises through differences in their electronic structure. The electron transfer between the mucus and the mucoadhesion results in the formation of bi-layer of electronic charges formed at the mucus and mucoadhesive system interface as shown in (fig. 4) [8,9].

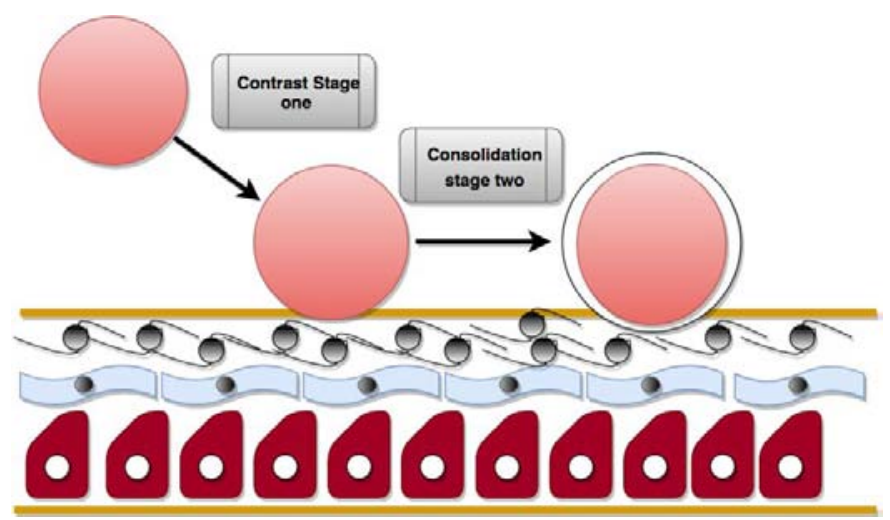

Fig. 3: Indicates the stages concerned with mucoadhesion: first stage shows the interaction of drug delivery system on the surface of mucus membrane; second stage shows several physicochemical interactions, results in prolonged adhesion at the site of action

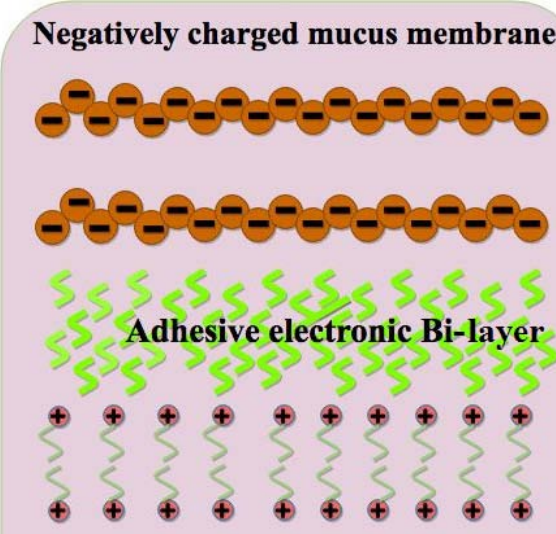

Positively charged polymeric system

Fig. 4: Adhesion between the mucus membrane (negative charge) and the polymeric system (positive charge), through differences in their electronic structure

\section{Fracture theory}

This theory describes the adhesive bonds between systems that are related to the force that are required to impart or separate both surfaces from one another. This includes that the force required for polymer detachment from the mucus to the basic strength of their adhesive bonds. It has been found that when the polymer network strands are longer, or the degree of cross-linking within system is reduced the greater will be the work of fracture. This theory also allows the determination or measurement of fracture strength $(\sigma)$ which leads to the separation of two surfaces using young's modulus of elasticity (E), the critical crack length (L) and the fracture energy $(\varepsilon)$ through following equation [9].

$$
\sigma=\sqrt{ }\left(E^{*} \varepsilon\right) / 1
$$

\section{Diffusion interlocking theory}

This theory is a two-way diffusion process which proposes the time dependent diffusion of mucoadhesive polymer chains into the glycoprotein chain network of the mucus layer and the penetration 
rate is being dependent upon the diffusion coefficient of both interacting polymers as indicated in (fig. 5) Moreover, there are many factors and properties that significantly influence this diffusion are cross-linking density, chain mobility or flexibility, molecular weight and expansion capacity of both networks and temperature (as important environmental factor). Although it is recognized that longer polymer chains may diffuse, interpenetrate and ultimately entangle to a greater extent with surface mucus, it should be recognized that a critical chain length of at least $100 \mathrm{kDa}$ is necessary to obtain interpenetration and molecular entanglement. Another significant contributory factor in determining interpenetration is the miscibility of both systems with one another. The time at which maximum adhesion occurs between two substrates during interpenetration has been supported by experimental evidence in recent studies using FTIR and rheological techniques, and may be determined using the depth of interpenetration and the diffusion coefficient [9].

\section{Mechanical theory}

The mechanical theory considers adhesion due to filling of irregularities on a rough surface by a mucoadhesive liquid.
Additionally, such irregularity increases the interfacial area available for interaction and can be considered the most important phenomenon of the process as depicted in (fig. 6) [10].

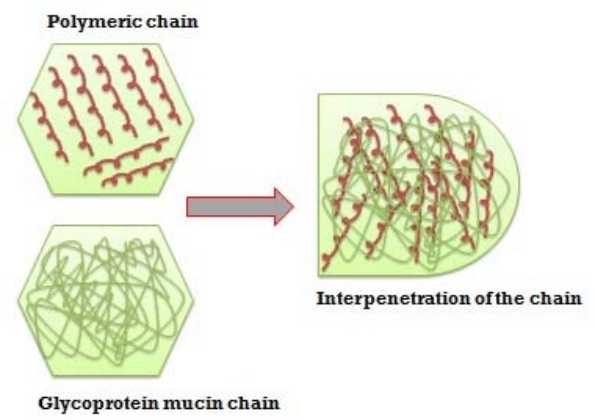

Fig. 5: Diffusion Interlocking of the mucoadhesive polymer with glycoprotein mucin chain

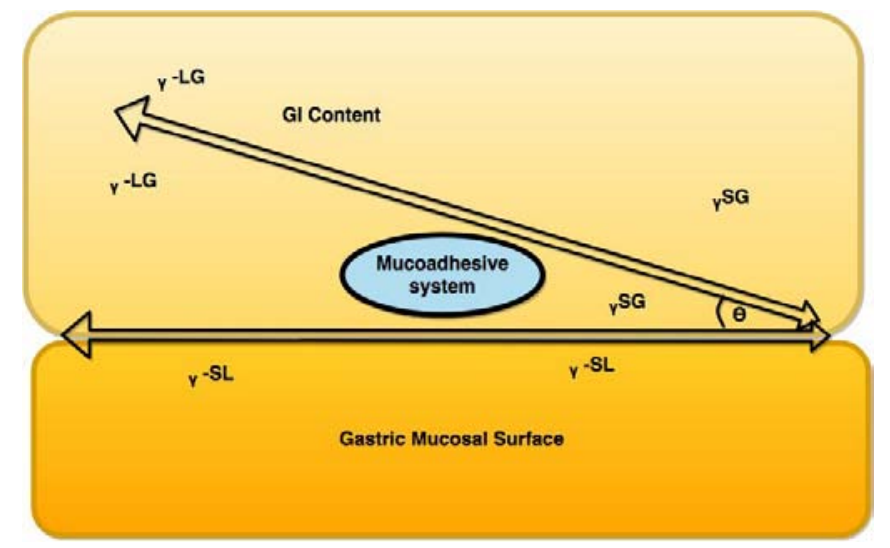

Fig. 6: Formation of contact angle between the gastric mucosal surface and the interface

\section{Muco-adhesive polymers}

Muco-adhesive polymers are mainly water soluble in nature however some can be water insoluble too. These polymers have swellable networks. Networks are joined with the help of some cross linking agents. These cross linking agents have various important properties which are required for muco-adhesion like easy wetting, better mutual adsorption and better penetration and interpenetration ability within the polymer and the oral mucus. These muco-adhesive polymers which have ability to bind with the mucus present on the epithelial cells surfaces can further be divided into three classes [11-13].

1. Polymers which have ability to become sticky when these are placed in water. These polymers also have their own muco-adhesion power to achieve better stickiness. Examples are collagen, gelatin, starch, alginate, and agarose [14].

2. Polymers which have ability to adhere with the epithelia surface by virtue of their electrostatic nature (Hydrogen bonding can play significant role in these polymers in order to achieve better adhesion). Examples are carboxy methyl cellulose, carbopol, sodium alginate, hydroxyl propyl methyl cellulose [15].

3. Polymers that have ability to bind with the specific receptors and hence can be helpful in order to achieve better drug targeting through their site specific recognition power [16].

Some important characteristics of ideal muco-adhesive polymers

The mucoadhesive polymer as well as its degradation products must be non-toxic in nature. Other than the non-toxicity these degradation products and the polymer should be non-absorbable from the site of administration. The mucoadhesive polymer as well as its degradation products must be non-irritant to mucous surface where it is applied. The mucoadhesive polymer as well as its degradation products should have ability to form strong non covalent bonds with mucin epithelial cells [17]. This will avoid the polymeric buccal formulation to shift from the site of administration because of the buccal movements which are produced by talking, drinking and eating etc. The mucoadhesive polymer should have ability to adhere quickly to most of the tissues where it is applied. It should also have site specificity[18]. The mucoadhesive polymers should have ability to allow the incorporation of the daily requirement of the drug. These polymers should not produce any hindrance in the way of drug release. These polymers should not decompose during their storage period. These should have required shelf life which can help to make the preparation same as before without any degradation for long period of time. These musoadhesive polymers should be low of cost and should be easily accessible and easy to produce and manufacture [19].

\section{Classification of muco-adhesive polymers}

These muco-adhesive polymers can be divided into two broad categories:

Natural Polymers: Derived from natural origin for example: collagen, albumin, alginates, gelatin, cyclodextrins, chitosan, dextran, starch, agarose, cellulose, hyaluronic acid extra.

Synthetic polymers: These are further divided into two categories:

A) Bio-degradable polymers: Polylactic acid, Polyhydroxyl butyrate, Polyglycolic acid, Polycaprolactone, Poly-Doxanones, Polyadipic acid, 
Polysebacic acid, Polyterphthalic acid, Poly iminocarbonates, Poly amino acids, Polyphosphates, Polyphosphazenes, Polyphosphonates, Poly urethanes, Polyacetals, Poly-ortho esters etc [20].

B) Non biodegradable polymers: Carboxymethylcellulose, Ethyl cellulose, Polydimethyl siloxanes, Cellulose acetate HPMC, Collodial silica, Polymethacrylates, Poloxamines etc.

Polymers used in buccal drug delivery based upon their category are depicted in (table 1) [21].

\section{Natural polymers \\ Collagen}

Collagen is one of the natural protein polymers which is widely used for muco-adhesion. Collagen polymer has a triple helical structure. With time the collagen polymer is further modified and various types of these polymers have been isolated. There are about nineteen different types of collagen monomers which have been isolated, characterized, and tested for both pharmaceutical and medical interests [22]. Collagen has various attractive properties like good biocompatibility, degradability, low antigenicity which makes the collagen polymer to be used widely in various pharmaceutical, tissue and medical applications in drug delivery systems [23].

Abruzzo et al., 2012, successfully discovered buccal delivery of active drug propranolol hydrochloride by using chitosan and gelatin dual polymeric films. The FT-IR and TGA studies showed that there are appropriate and acceptable interactions between the gelatin and chitosan polymers. The investigator used the high concentration of chitosan in the chitosan/gelatin films because by using the high amount of chitosan there is lowest percentage of water uptake ability which is found to be about $235.1 \pm 5.3 \%$ [24]. The high amount of chitosan in the dual polymeric films also helped in high residence time of the prepared formulation in the buccal cavity when tested in vivo. The residence time was found to be about $240 \pm 13 \mathrm{~min}$. The use of mannitol in prepared formulation showed better permeation of the drug when tested through porcine buccal mucosa. Near about $80 \%$ drug permeation was found when tested on porcine buccal mucosa when applied for around $5 \mathrm{~h}$. Another interesting point of using the chitosan/gelatin conjugated dual polymeric films was their better compatibility with the microflora environment of buccal mucosa [25].

\section{Gelatin}

Gelatin is an example of natural polymers commonly found in nature. Gelatin is a water soluble polymer which is basically produced through the process known as denaturation. Denaturation of collagen polymer resulted in the formulation of gelatin [25]. This polymer is also widely used in pharmaceutical, tissue and medical applications. Gelatin polymer has outstanding physical and chemical properties. It is biocompatible, biodegradable and of low antigenicity. Gelatin is also a supporting material which can be used for cell culture, gene delivery and tissue engineering. The formulations, in which gelatin is used, have the ability to incorporate as well as release the bioactive agents like active drugs, proteins and peptides, dual growth factors etc. [26].

\section{Albumin}

In order to prepare muco-adhesive gels by using albumin, it is first modified by conjugating with the PEG. These modified albumin containing hydrogels were later used in tissue engineering scaffold materials. Albumin and its derivates are widely used for drug delivery by various pharmaceutical researchers. These are also used in tissue engineering applications. These polymers have adequate biocompatibility, low toxicity, biodegradability, nonimmunogenicity, relatively low cost, water solubility, gelling ability, high viscosity and stabilizing properties [27].

\section{Dextran}

Dextran is also one of the most widely used natural polymer for mucoadhesive gel formulation. This dextran polymer is a type of natural linear polymer in which 1-6 glucopyranoside linked polymer. Dextran is basically synthesized from certain types of lactic acid bacteria mainly Leuconostoc mesenteroides, Streptococcus mutants. These pharmaceutical polymers have ability to get better water solubility, better biocompatibility, and appropriate biodegradability $[28,29]$.

\section{Chitosan}

Chitosan and its derivates are widely used for drug delivery by various pharmaceutical researchers [30]. These are also used in tissue engineering applications. These polymers have adequte biocompatibility, low toxicity, biodegradability, nonimmunogenicity, relatively low cost, water solubility, gelling ability, high viscosity and stabilizing properties [31]. Peluso et al., 2012, have successfully discovered the gels for local application in the buccal inflammation which is found to be a promising gel to reduce toxicity at the site of administration [32]. In the study, the investigators do the in vitro study and performed the characterization of chitosan based polymeric gels to test the action of formulation in buccal mucosal epithelial cells. The rheological properties of the prepared gels were tested by using cone-plate rheometer [33]. The in vitro showed better drug release and high permeability on pig cheek mucosa. The mucoadhesion ability was tested by using universal test machine [34]. All the results showed the prepared gels containing chitosan a better candidate to treat the oral disorders [35]. Factors affecting mucoadhesion of natural and synthetic polymers are depicted in [table 2].

Table 1: Examples of polymers used in buccal drug delivery (BDD)

\begin{tabular}{|c|c|c|c|}
\hline Criteria & Category & Examples & References \\
\hline \multirow[t]{9}{*}{ Source } & Semi-natural/natural & Agarose, chitosan, gelatine & \\
\hline & Synthetic & Hyaluronic acid & [36] \\
\hline & & Various gums (xanthan, guar, gellan, pectin and sodium alginate) & [37] \\
\hline & & Cellulose derivatives & \\
\hline & & (CMC, thiolated CMC, sodium CMC, HEC, HPC, HPMC, MC) & \\
\hline & & Poly(acrylic acid)-based polymers & \\
\hline & & (CP, PC, PAA, copolymer of acrylic acid and PEG) & \\
\hline & & Others & \\
\hline & & PVA, PVP, thiolated polymers & \\
\hline \multirow{2}{*}{$\begin{array}{l}\text { Aqueous } \\
\text { solubility }\end{array}$} & Water solubility & CP, HEC, HPC, HPMC PAA, sodium CMC, sodium alginate & [38] \\
\hline & Water-insoluble & Chitosan, EC, PC & [39] \\
\hline \multirow[t]{4}{*}{ Charge } & Cationic & Aminodextran, dimethylaminorthyl (DEAE)-dextran trimethylated chitosan & {$[40]$} \\
\hline & Anionic & Chitosan-EDTA, CP, CMC, pectin, PAA, PC, sodium alginate, sodium CMC, xanthan & [41] \\
\hline & Non-ionic & gum & [42] \\
\hline & & Hydroxyethyl starch, HPC, PVA,PVP, scleroglucan & \\
\hline \multirow{3}{*}{ Bioadhesive force } & Covalent & Cyanoacrylate & [43] \\
\hline & Hydrogen bond & Acrylates [hydroxylated methylate, poly(methacrylic acid)], CP, PC, PVA & [44] \\
\hline & $\begin{array}{l}\text { Electrostatic } \\
\text { interaction }\end{array}$ & Chitosan & {$[45]$} \\
\hline
\end{tabular}


Table 2: Various factors affecting the mucoadhesion of natural and synthetic polymers

\begin{tabular}{|c|c|c|c|}
\hline $\begin{array}{l}\text { S. } \\
\text { No. }\end{array}$ & Factors affecting & Details & References \\
\hline 1 & $\begin{array}{l}\text { Flexibility of } \\
\text { polymeric chains }\end{array}$ & $\begin{array}{l}\text { It is one of the important factors which affect the polymeric mucoadhesion. The mucoadhesion } \\
\text { strength depends upon the polymer flexibility. The appropriate flexibility of the polymer within the } \\
\text { standard limits shows increase in degree of diffusion through the mucus layer which further results } \\
\text { in better and strong mucoadhesion. It is seen than most of the water soluble (hydrophilic) polymers } \\
\text { show lower flexibility and hence have less depth of penetration resulting in low strength of } \\
\text { mucoadhesion. }\end{array}$ & {$[46]$} \\
\hline 2 & $\begin{array}{l}\text { The ability of the } \\
\text { polymer to show } \\
\text { hydrogen bonding }\end{array}$ & $\begin{array}{l}\text { If the polymer showed strongest bonding that is covalent bonding then because of very high } \\
\text { bioadhesion, the formulation become toxic to the body. The polymers which have ability to show } \\
\text { hydrogen bonding are accepted here because they show bioadhesion too with the acceptable } \\
\text { strength. Higher the capacity of producing the hydrogen bonding, higher will be the increase in total } \\
\text { adhesion. }\end{array}$ & {$[47]$} \\
\hline 3 & $\begin{array}{l}\text { Polymer } \\
\text { concentration }\end{array}$ & $\begin{array}{l}\text { The optimization of polymer concentration can help in producing the mucoadhesion with required } \\
\text { strengths like high, medium or low. High the Polymer strength high will be the polymeric } \\
\text { mucoadhesion. However, its low concentration will represent in low mucoadhesion strength. High } \\
\text { polymeric strength represents high amount of polymeric networks for the interaction with the } \\
\text { mucous which produces better mucoadhesion. }\end{array}$ & {$[48]$} \\
\hline 4 & $\begin{array}{l}\text { Molecular weight of } \\
\text { the polymer }\end{array}$ & $\begin{array}{l}\text { It has been seen that different polymers show good adhesion property with mucin epithelial cells } \\
\text { layer only at most favorable molecular weight amount of the polymer. Usually, it has been seen that } \\
\text { the optimum molecular weight of the polymer ranges from } 1 \times 10^{4} \text { to } 4 \times 10^{6} \text { Daltons. Usually high } \\
\text { molecular weight of the polymeric structure resulted in the increase in the entanglement between } \\
\text { the mucin layer network and the polymeric structure. However, Low molecular weight of the } \\
\text { polymeric structure resulted in the increase in the flexibility of the polymeric chain which further } \\
\text { increases the penetration process which further resulted in increase in degree of diffusion through } \\
\text { the mucus layer which further results in better and strong mucoadhesion. }\end{array}$ & [49] \\
\hline 5 & Degree of hydration & $\begin{array}{l}\text { Wettability is important since the polymeric formulation need to be in contact with the mucin layer } \\
\text { at the very first stage. Only after that penetration and mucoadhesion will take place. High wettability } \\
\text { becomes important at the initial stage of contact of the polymeric surface with the mucous layer. } \\
\text { However it is important to note that the degree of hydration should be in the required range. } \\
\text { Because lesser wettability will result in lesser degree of contact and hence lesser mucoadhesion } \\
\text { between the polymeric surface with the mucous layer. However high wettability will result in the } \\
\text { slippery contact between polymeric surface with the mucous layer which resulted in the lesser } \\
\text { mucosdhesion. }\end{array}$ & {$[50]$} \\
\hline 6 & Cross-linking density & $\begin{array}{l}\text { Increase in the cross-linking density of the polymer would result in the decrease of the adhesion } \\
\text { between the polymeric surface and the mucous layer. This is because of the decrease in the polymer } \\
\text { network mobility. }\end{array}$ & {$[51]$} \\
\hline 7 & $\begin{array}{l}\text { Molecular charge on } \\
\text { the polymer }\end{array}$ & $\begin{array}{l}\text { Cationic charge on the surface of the polymer enhances the interaction between its surface and } \\
\text { mucin. This is because of the high electrostatic attractions as the mucin carries negative charge on } \\
\text { its surface. On contrary, the use of anionic polymer reduces the chances of mucoadhesion because of } \\
\text { reduced electrostatic attractions between polymeric surface and mucin layer. }\end{array}$ & {$[52]$} \\
\hline 8 & Ionic Strength & $\begin{array}{l}\text { Ionic strength whether it is cationic or anionic strength can affect the internetwork between the } \\
\text { structure of polymer and mucin layer of the epidermal cells. This is mainly because of the change in } \\
\text { the polymeric structures. The conformation of polymeric structures changes with the change in the } \\
\text { ionic strength (or shift in the environmental conditions from anionic to cationic or from cationic to } \\
\text { anionic). }\end{array}$ & [53] \\
\hline 9 & $\begin{array}{l}\text { Moisture level at the } \\
\text { site of administration }\end{array}$ & $\begin{array}{l}\text { The moisture level of the mucin layer also affect the degree of mucoadhesion. This moisture level } \\
\text { varies with the type of body part where mucin layer is present. In the buccal cavity usually moisture } \\
\text { level is high so will not cause any problem regarding mucoadhesion. However, during the buccal } \\
\text { disorders like dryness of mouth and some other related disorders, this moisture level can change } \\
\text { which may impact the degree of mucoadhesion. The degree of swelling of polymer also depends } \\
\text { upon the moisture level present at the site of administration. }\end{array}$ & {$[54]$} \\
\hline 10 & $\begin{array}{l}\text { Applied pressure or } \\
\text { force }\end{array}$ & $\begin{array}{l}\text { The depth of the mucoadhesion penetration is affected by the amount of total force or pressure } \\
\text { which is applied on the delivery systems. By using the appropriate strength and suitable contact } \\
\text { time, an adequate mucoadhesion can be achieved. }\end{array}$ & {$[55]$} \\
\hline
\end{tabular}

\section{Buccal drug delivery system}

In 1847, it was first ever discovered that the drug absorption can also be possible when it is given through buccal cavity. The systemic absorption of the drug when it is given through buccal cavity is first ever tested on 1935. The results showed better results with better patient compliance as compared to other routes like nasal, ocular, vaginal extra routes. The buccal cavity is easily reachable (accessible) and heal itself rapidly after any damage of local stress. The buccal lining is also one of the robust lining of human body and can be used for systemic drug delivery [56]. As compared to other oral linings like sublingual route (floor of the mouth) [57], gingival route (gums) [58], linings around the lips, palatal mucosal route etc. [59], The buccal lining have different permeability to selective drugs, different anatomy, and desired length in order to keep the hold on the drug delivery dosage form like patches, tablets, semi-solid dosage form [60]. This buccal lining can be used not only for local drug delivery but can also be used for systemic drug delivery with better bioavailability. The local therapy by using buccal route mainly included the treatment of diseases like oral candidiasis, xerostomia, neuropathic pain, oral cancer, mucositis, dental caries, oral lesions, gingivitis, severe dryness of mouth due to lack production of saliva or lack in release of saliva etc [61-63]. The systemic therapy by using buccal route mainly includes the treatment of disorders in which prolonged and sustained release of drug is required. The buccal route is mainly used due its better trans-mucosal permeability which allows huge types of drugs to penetrate through it and reaches the systemic circulation [64]. However when compared with the sublingual route, buccal route becomes less permeable and does not allow the rapid action of the drug. In other words, the onset of action is slow when we select buccal route for drug delivery. However, this disadvantage of buccal route becomes advantageous if 
we want to get prolonged and sustained release of the drug [65]. Hence, for the scientists, working on diseases where long release of drug is required with better bioavailability, then they prefer buccal route. This is because, the buccal route has a smooth, immobile and large surface which makes it better route for retentive drug delivery systems so that prolonged and sustained release of drug can be achieved [66].

\section{Advantages and disadvantages of buccal drug delivery}

\section{Advantages}

o The buccal lining is highly vascularised and better accessible for any dosage form to get better administered in the impacted area and can be easily removed from the impacted area.

\section{o Better patient compliance.}

o Buccal mucosa does not have the same harsh environmental factor like pH, enzymatic degradation, temperature sensitivity etc. as that of oral mucosa and hence can be used for harsh environment sensitive drugs.

o As compared to other mucosal routes, in the buccal route there is very low enzyme activity. Hence, there is less enzymatic degradation of drug

o Buccal delivery protects the active drug from acid hydrolysis which is possible in gastrointestinal tract and hence is helpful in avoiding the first pass metabolism of drug.

\section{Disadvantages}

o When compared with the sublingual route, buccal route becomes less permeable and does not allow the rapid action of the drug.

o There is continuous salivary secretion in the mouth, near about $0.5-2$ liters per day. Such continuous salivary secretions lead to the dilution of the drug reducing the drug effectiveness.

\section{Various dosage form available for buccal delivery}

Till date various dosage forms like semisolid dosage forms (ointments, gels, pastes), tables, capsules etc. have been discovered which can be used in the buccal route for the drug release. Some of these dosage forms have been explained below:

\section{Semi-solid dosage forms (gels, pastes, ointments)}

Various semi-solid dosage forms like gels, ointments, pasts etc have been used in the oral buccal cavity. The sticky nature of these gels, ointments and pastes, resulted in better contact with the mucosal layer and the hydrophobic nature of the polymer used within these dosage forms do not allow the formulation to get diluted by salivary release [67].

Bioadhesive gels (Bioadhesive ointments) are frequently used for local wound therapy of the oral cavity. Bioadhesive pastes are also used for oral cavity. Now a day, most popularly used bioadhesive paste is marketed as Orabase. Orabase is a type of first generation bioadhesive paste and is widely used to treat mouth ulcers for a long time period. The paste acts as a barrier between the ulcers and saliva and do not allow the drug to get diluted and hence allow better and more penetration of drug to treat ulcers. The paste basically consists of finely ground pectin, fine gelatin and sodium CMC is dispersed in the combination of mineral oil and polyethylene gel base. This combination of mineral oil and polyethylene gel help to maintain the paste at its application site for about 15-150 $\mathrm{min}$ [68]. Usually the neutral poly-methacrylic acid and methyl ester were also used in the Orabase in order to avoid the irritation which is caused by the conventional ointments. The Bioadhesive ointments are usually more viscous then the bioadhesive gels and pastes and the high viscosity ointments usually contain carbopol (CP), which is mainly responsible for the high viscosity [69]. About $12.5 \%$ concentration of carbopol mainly responsible for sustained release of the drug from the ointment and showed increase in the absorption of the drug for about $5 \mathrm{~h}$ as compared to pastes/gels [70]. The release of Prednisolone drug in the high viscosity carbopol containing ointment in combination with the white petrolatum base has been tested by some researchers and the results showed better results as compared to that of pastes and gels containing same amount of active drug (Prednisolone) [71].

Other than pastes, gels, ointments, the use of hydrogels has also been discovered in order to treat buccal cavity related disorders. In 1961, the first hydrogels are prepared by using poly (2-hydroxy ethyl methacrylate) by Wichterle and Lim. Hydrogels are basically hydrophilic polymer networks which are oriented in a three dimensional orientation. These hydrogels are capable to swell in water and also equally capable to spread in biological fluids like saliva. These hydrogels are able to absorb water just because of the presence of various types of hydrophilic group's like- $\mathrm{OH},-\mathrm{COOH}$,$\mathrm{CONH} 2,-\mathrm{CONH},-\mathrm{SO} 3 \mathrm{H}$ etc [72]. The drug release from the hydrogels can be controlled and release mechanisms of the drug from the hydrogels can be modified by adjusting the factors like water content, polymer composition, crystallinity, and crosslinking density [73]. The delivery of lidocaine hydrochloride drug is tested by using the hydrogel prepared from the chitosan glutamate polymer. Chitosan glutamate polymer is basically a soluble salt form of the chitosan polymer. The buccal delivery of the drug lidocaine hydrochloride as an anaesthetic drug is found to show effective and better relief buccal cavity disorders like aphthosis and some other painful buccal cavity diseases [74].

\section{Tablets}

Although semi-solid dosage forms are easy to administer and comfortable, however the active ingredient stability in the semisolid dosage forms is comparatively less as compared to the tablets. The tablets as well as patches offer better drug stability, long period of therapeutic drug concentration level at site of action and improved residence time [75]. These days some engineered tablets and patches have multi-layer systems and matrix devices. These engineered tablets contain adhesive layer and some other drug layers from which drug is released continually for long period of time $[76,77]$. One more layer considered as drug impermeable layer is also included in these engineered and matrix tablets, to enhance the drug release unidirectional. This unidirectional release mechanism of the drug is important because this avoid the clearance of the drug through saliva released by the salivary glands. The most appropriate site of administration for the tablets, which avoids the chances of drug clearance from the buccal cavity, is by administrating the tablets or any other dosage form under the upper lip of the buccal cavity [78]. The marketed Buccastem ${ }^{\circledR}$, is an adhesive tablet used for anti-emetic action. This buccastem contains the active ingredient as prochlorperazine maleate which is placed under the upper lip and shows better release of drug for prolonged period of time. Other than these benefits of using the oral buccal tablets, some other mechanisms like oscillatory action produced by talking and mastication action produced during chewing of any eatable item, can produce patient compliance making the use of tablets uncomfortable $[79,80]$.

Till date a large number of muco-adhesive tablets have been investigated which are considered to have better muco-adhesive strength as they are used in combination with different polymers: Some of these muco-adhesive tablets have been mentioned below (table 3).

\section{Powder dosage forms}

Basically, a physical mixture of the drug with the bio-adhesive polymer can act as the powder dosage form which can be sprayed to the buccal mucosa in order to treat buccal disorders. Yamamoto et al., have successfully prepared a bio-adhesive buccal powder containing hydroxypropyl cellulose and active drug as beclomethasone diproprionate. The prepared bio-adhesive powder is then sprayed on the buccal cavity of the rats and the results were evaluated. The results showed that there is a significant increase in the residence time when we spray the powdered dosage form on the buccal cavity as compared to the related oral solution containing same drug and polymer in same concentration. The results showed that there was about $2.5 \%$ retention power of the active ingredient beclomethasone on the buccal mucosa after spraying for about $4 \mathrm{~h}$ [104]. 
Table 3: Various combinations of API and polymers used in mucoadhesion of solid and semi-solid dosage form

\begin{tabular}{llll}
\hline S. No. & Active ingredient used & Polymer used & Reference \\
\hline 1 & Nifedipine & Sodium alginate, Poly Vinyl Pyrollidone, and Poly Ethylene Glycol & {$[81]$} \\
2 & Nimesulide & Carbomer & {$[82]$} \\
3 & Ondansetron & Sodium carboxy methylcellulose, Hydroxy propylmethylcellulose & {$[83]$} \\
4 & Metoclopramide & Sodium carboxy methylcellulose, Hydroxy propylmethylcellulose & {$[84]$} \\
5 & Benzydamine & Gelatin, Sodium carboxy methylcellulose, Hydroxy propylmethylcellulose & {$[85]$} \\
6 & Lignocaine HCl & Sodium carboxy methylcellulose, Poly Vinylpyrollidone & {$[86]$} \\
7 & Ergotamine tartrate & Carboxyvinyl polymer and Hydroxy Propyl Cellulose & {$[87]$} \\
8 & Cyanocobalamin & Polyoxyethylene & {$[88]$} \\
9 & Chlorpheniramine maleate & Polyoxyethylene & {$[89]$} \\
10 & Baclofen & Sodium carboxymethyl celulose, sodium alginate, and Methocel & {$[90]$} \\
11 & Ketoprofen & Sodium alginate and shitosan & {$[91]$} \\
12 & Lactoferrin & Sodium alginate & {$[92]$} \\
13 & Omeprazole & Sodium alginate, Hydroxy propyl methyl cellulose & {$[93]$} \\
14 & Salmon calcitonin & Hakea gum obtained from Hakea gibbosa & {$[94]$} \\
15 & Propranolol HCl & Sodium carboxymetyl cellulose & {$[95]$} \\
16 & Pravastatin sodium & Carageenan & {$[96]$} \\
17 & Piroxicam & Hydroxy propyl methyl cellulose & {$[97]$} \\
18 & Morphine sulfate & Hydroxy propyl methyl cellulose & {$[98]$} \\
19 & Metoprololtartarate & Sodium carboxy methylcellulose, Hydroxy propylmethylcellulose & {$[99]$} \\
20 & Testosterone & Drum dried waxy maize & {$[100]$} \\
21 & Itraconazole & Carbopol 934P, HPMC, Eudragit E 100 & {$[101]$} \\
22 & Furosemide & Soluphore, PEG 400, Polyvinyl alcohol, Cremophore, Eudragit, HPMC & {$[103]$} \\
23 & Ranitidine & HPMC, Carbopol 934P, Sodium Biocarbonate & \\
\hline
\end{tabular}

\section{Polymeric films}

Polymeric films are mainly used as coating formulation for various pharmaceutical tablet dosage forms, and the use these films was not attempted for buccal release. Later on 1990, the buccal film were considered to be more preferable over other adhesive dosage forms like tablets, capsules etc. as these polymeric buccal films have better flexibility and comfort related properties [105]. In addition to these properties, buccal polymeric films can show comparatively better residence time on the mucosa as compared to other dosage forms which can be easily diluted and easily washed away and can be removed from the buccal cavity by saliva. Other than these, these buccal polymeric films have the ability to protect the wound surface from various other bacterial infectious diseases and they are also helpful in reduction of pain [106].

Better flexibility, elasticity and softness are the ideal properties of polymeric buccal film. An ideal polymeric buccal film should also have be adequately strong so that it can withstand the stress conditions produced by mouth activity and should not get broken into pieces in mouth. In addition to these properties, an ideal polymeric buccal film must also have good bio-adhesive strength such that it should retain in the required area without breakage for the desired period of time [107]. Swelling of the polymeric films is a very common problem which cannot be neglected and cannot be completely removed. However, it can be reduced to some extent. An ideal polymeric buccal film if swell, then the swelling should be in the required range, such that it should not alter the physical and mechanical properties of the film [108]. The elasticity, softness, flexibility, bio-adhesive strength and other related properties should not get changed with the swelling of the film. Hence, we can say that the bio-adhesive, mechanical and swelling properties are the most critical properties in order to judge the efficiency of polymeric buccal film and hence these properties should be evaluated properly with standard tests and procedures [109]. These days polymeric buccal films have been prepared by using polymers like sodium CMC, PEG 400, CP
934P, HPMC, PEG 400 etc. It has been seen that HPMC (hydroxypropyl methylcellulose) related polymeric buccal films were tougher and have more elasticity with more bio-adhesive property as compared to the polymeric buccal films prepared from sodium CMC films [110]. In vivo studies have also showed that the polymeric buccal films containing HPMC showed tolerable swelling as compared to the polymeric buccal films containing sodium CMC [111].

\section{Polymeric patches}

On the other hand, polymeric buccal bio-adhesive patches are laminated thin films which can be single or multi layered depending on the need. These patches are available in various shapes. These patches can be round or can be oval in shape. These polymeric buccal patches have drug reservoir layer which is further connected with impermeable layer known as backing layer. This backing layer is very helpful in providing the unidirectional flow of the drug, contained in the polymeric layer, across buccal mucosa. These patches can be 1-3 $\mathrm{cm}$ of range in their sizes. This small size of the polymeric buccal patch makes them more convenient and more comfortable for the user and hence increases the patient compliance. An ideal buccal polymeric patch should be flexible and ellipsoid in the shape so that it can fit easily onto the centre of buccal mucosa [112].

The drug Acyclovir was delivered in the buccal cavity by using the polymeric buccal adhesive patches. The patch contained the polymer PEG, with copolymer acrylic acid, monomethyl ether monomethacrylate, an impermeable layer which is helpful in preventing the excessive dilution and washout through saliva. The in vivo studies showed that the patch once administered on the site remain there and releases the active drug Acyclovir for a period of about $22 \mathrm{~h} \mathrm{[113].} \mathrm{These} \mathrm{evaluation} \mathrm{tests}$ showed it a good candidate for buccal delivery of the drug.

Some literatures were studied in which the authors mentioned the formulation which contains API and some polymers (table 4).

Table 4: Various combinations of API and polymers used in the formulation of mucoadhesive patches for buccal drug delivery

\begin{tabular}{llll}
\hline S. No. & Active ingredient used & Polymer used & Reference \\
\hline 1 & Isosorbide dinitrate & HPMC phthalate & {$[114]$} \\
2 & Lidocaine & Hydroxy propyl Cellulose & {$[115]$} \\
3 & Nifedipine & Sodium alginate, Poly Ethylene Glycol & {$[116]$} \\
4 & Protirelin & Poly Vinyl Pyrrolidone & {$[117]$} \\
5 & Tetracaine & Hydroxy Propyl Cellulose & {$[118]$} \\
6 & Ofloxacin & Hydroxy Propyl Cellulose & {$[119]$} \\
7 & Tetracycline & Atelocollagen & {$[120]$} \\
8 & Triamcinolone acetonide & Poloxamer, Hydroxy propyl methylcellulose \\
9 & Insulin & Gelatin & {$[121]$} \\
10 & Glibenclamide & Chitosan & {$[122]$} \\
\hline
\end{tabular}


Table 5: Commercial formulation intended for buccal delivery

\begin{tabular}{|c|c|}
\hline Product & Manufacturer \\
\hline \multicolumn{2}{|l|}{ Testosterone Buccal Tablet (Straint) } \\
\hline Desmopressin Buccal Tablet & Columbia Laboratories Inc. \\
\hline \multicolumn{2}{|l|}{ Androdiol Buccal tablets (Cyclo-Diol SR) } \\
\hline Norandrodiol Buccal Tablets (Cyclo-Nordiol SR) & Ergo Pharm \\
\hline Insulin Buccal Spray & Generex Biotechnology Corporation \\
\hline \multicolumn{2}{|l|}{ ORALGEN (US) } \\
\hline \multicolumn{2}{|l|}{ ORALIN (Canada) } \\
\hline Pilocarpine Buccal Tablet (PIOLOBUC) & Cytokine Pharma Sciences Inc. \\
\hline Glyceryl Trinitrate (Suscard Buccal Tablet) & Pharmax Limited \\
\hline Prochlorperazine Buccal Tablets (Buccastem) & Britannia Pharmaceutical Ltd. \\
\hline Oral Transmucosal Fentanyl Citrate Solid Dosage Form (ACTIQ) & Cephalon Inc. \\
\hline Vitamins Trans Buccal Spray & Regency Medical research \\
\hline Lorazepam Buccal Tablets & Wyeth Pharmaceuticals \\
\hline \multicolumn{2}{|l|}{ Oxazepam Buccal Tablets } \\
\hline Nicotine Mucoadhesive Tablets & Leo Pharmaceuticals \\
\hline \multicolumn{2}{|l|}{ Nicotine Chewing Gum } \\
\hline \multicolumn{2}{|c|}{ Prochlorperazine Bioadhesive Buccal controlled release Tablet(Buccastem) } \\
\hline Buprenorphine $\mathrm{HCl}$ Tablets (Subutex) & Reckitt Benckiser \\
\hline \multicolumn{2}{|l|}{ Buprenorphine $\mathrm{HCl}$, Naloxone $\mathrm{HCl}$ (Suboxane) } \\
\hline Methyltestosterone Buccal Tablets (Metandren) & Ciba-Geigy \\
\hline
\end{tabular}

Table 6: Mucoadhesion polymers and their bioadhesion strength

\begin{tabular}{|c|c|c|c|}
\hline S. No. & $\begin{array}{l}\text { bioadhesion strength } \\
\text { high }\end{array}$ & $\begin{array}{l}\text { Bioadhesion strength } \\
\text { medium }\end{array}$ & $\begin{array}{l}\text { Bioadhesion strength } \\
\text { low }\end{array}$ \\
\hline 1 & Carboxymethylcellulose & Gelatin & Polyethylene glycol \\
\hline 2 & Tragacanth & Guar Gum & Psyllium amberlite \\
\hline 3 & Sodium alginate & Gum Karaya & Thermally modified starch \\
\hline 4 & Carbopol 934 & Chitosan & Hydroxypropylcellulose \\
\hline 5 & Poly(acrylic acid/divinyl benzene) & Acacia & Polyvinyl pyrrolidone \\
\hline
\end{tabular}

Table 7: Patented mucoadhesive formulations

\begin{tabular}{|c|c|c|c|}
\hline Patent number & Inventor & Original assignee & Title \\
\hline US9320721B2 & Ulrike Vollmer & TESA LABTEC GmbH & $\begin{array}{l}\text { Mucoadhesive patch with opposite ratios of nonionic and } \\
\text { anionic hydrocolloids in adhesive and backing layer }\end{array}$ \\
\hline US20020142042A1 & Russell Mumper, Michael Jay & $\begin{array}{l}\text { University of Kentucky } \\
\text { Research Foundation }\end{array}$ & $\begin{array}{l}\text { pH-sensitive mucoadhesive film-forming gels and } \\
\text { wax-film composites suitable for topical and mucosal } \\
\text { delivery of molecules }\end{array}$ \\
\hline EP2509586A1 & $\begin{array}{l}\text { Pierre Attali, Dominique } \\
\text { Costantini, Caroline Lemarchand }\end{array}$ & BioAlliance Pharma SA & $\begin{array}{l}\text { Mucoadhesive buccal tablets for the treatment of } \\
\text { orofacial herpes }\end{array}$ \\
\hline EP1231900A1 & $\begin{array}{l}\text { David Francis Bain, Dale Munday, } \\
\text { Calum Park, Omar Shakoor }\end{array}$ & $\begin{array}{l}\text { The Robert Gordon University, } \\
\text { Univ Robert Gordon }\end{array}$ & Bilayered buccal tablets comprising nicotine \\
\hline EP3173067A1 & $\begin{array}{l}\text { Ayca Yildiz Pekoz, Yildiz ozsoy } \\
\text { Erginer, Derya Arslan }\end{array}$ & Yildiz Pekoz Ayca & Mucoadhesive buccal in situ gel formulation \\
\hline US8529939B2 & David B. Masters, Eric P. Berg & Gel-Del Technologies Inc & $\begin{array}{l}\text { Mucoadhesive drug delivery devices and methods of } \\
\text { making and using thereof }\end{array}$ \\
\hline EP1107733A1 & Douglas Joseph Dobrozsi & Procter and Gamble Co & Oral liquid mucoadhesive compositions \\
\hline W02006105615A1 & $\begin{array}{l}\text { Ernest Alan Hewitt, } \\
\text { Richard James Stenlake }\end{array}$ & Ozpharma Pty Ltd & Buccal delivery system \\
\hline US8475832B2 & $\begin{array}{l}\text { Garry L. Myers, Samuel D. } \\
\text { Hilbert, Bill J. Boone, B. Arlie } \\
\text { Bogue, Pradeep Sanghvi, } \\
\text { Madhusudan Hariharan }\end{array}$ & RB Pharmaceuticals Ltd & Sublingual and buccal film compositions \\
\hline US20060198873A1 & $\begin{array}{l}\text { Shing Chan, Li-Lan Chen, } \\
\text { Dushendra Chetty, John Liu }\end{array}$ & SmithKline Beecham Corp & Orally dissolving films \\
\hline W02008077130A2 & $\begin{array}{l}\text { Hassan Nached, Keith Freehauf, } \\
\text { Peter Hanson }\end{array}$ & Merial Limited & Homogeneous paste and gel formulations \\
\hline US3257276A & $\begin{array}{l}\text { Robert H Broh-Kahn, Ernest J } \\
\text { Sasmor }\end{array}$ & $\begin{array}{l}\text { Laboratories for pharmaceutical } \\
\text { Development Inc }\end{array}$ & Oral analgesic preparation \\
\hline US5955098A & Harry A. Dugger, III & $\begin{array}{l}\text { Flemington Pharmaceutical } \\
\text { Corp }\end{array}$ & Buccal non polar spray or capsule \\
\hline US6110486A & Harry A. Dugger, III & Flemington Pharmaceutical Corp & Buccal polar spray or capsule \\
\hline US20090263476A1 & $\begin{array}{l}\text { Christopher N. Jobdevairakkam, } \\
\text { Vikram Katragadda }\end{array}$ & Navinta LLC & $\begin{array}{l}\text { Composition of Rapid Disintegrating Direct } \\
\text { Compression Buccal Tablet }\end{array}$ \\
\hline US20060002989A1 & $\begin{array}{l}\text { Salah Ahmed Lianli Li } \\
\text { Venkatesh Naini }\end{array}$ & Teva Women s Health Inc & $\begin{array}{l}\text { Formulations of sumatriptan for absorption across } \\
\text { biological membranes, and methods of making and } \\
\text { using the same }\end{array}$ \\
\hline CA1299105C & John A. Mccarty & Key Pharmaceuticals Inc & Buccal formulation \\
\hline
\end{tabular}




\section{Factors affecting polymeric bioadhesion}

1. Hydrophilicity of the drug.

2. Formulation type (Tablets, gels, semi-solid dosage forms, patches, films etc).

3. Molecular weight of the polymer used.

4. Hydrogen bonding and glass transition temperature of polymer used.

5. $\mathrm{pH}$ of saliva.

6. Buccal cavity movement by talking, drinking and eating etc.

7. Acid dissociation constant of the drug.

8. Concentration of the polymer used.

9. Swelling index of the polymer.

10. Contact time of prepared formulation on the applied surface.

\section{Gels}

Gels are the classical formulations which are used for topical administration of various drugs. These gels offer various beneficial properties as compared to other dosage forms for example: gels are easy to get applied on the surface, they show better spreadibility and better bio-compatibility. These gels also show better physicochemical properties which make these gels more appropriate dosage formulations as compared to others. For example, Hydrogels [124]. These hydrogels are modified form of gels with better hydrophilicity which make them easy to penetrate and better spreadibility. Hydrogels are three dimensional polymers with better cross linking which are basically synthesized from same or different monomers with hydrophilic nature [125]. These polymers have the ability to shrink or swell depending upon the environmental conditions where they have applied. Hydrogels have ability to get modified as per the needs of the drug's physical and chemical properties which itself increases the stability and release of the drug incorporated. The gels have three dimensional cross linking structures and hence there are a number of gaps in between these linking where the drug can be easily placed. All these properties make the gels a better candidate for tissue engineering, regenerative medicine, diagnostic biomedical sensors, and controlled drug delivery [126]. List of patented mucoadhesive formulation is depicted in (table 7).

\section{CONCLUSION}

This outline is about the mucoadhesive dosage forms which may be constructive tool for the capable of designing novel mucoadhesive drug delivery system as it offers prolonged contact at the site of administration. The formulation of mucoadhesive drug delivery system depends on the selection of appropriate polymer with immense mucosal adhesive properties and biocompatibility. There is no uncertainty that the oral route is the most favorable route of drug delivery. Mucoadhesive drug delivery has diverse applications including development of novel mucoadhesive, design of the novel devices, mechanisms and permeation enhancement.

\section{ACKNOWLEDGEMENT}

The authors gratefully acknowledge Dr. Madhu Chitkara, Vice Chancellor, Chitkara University, Rajpura, Punjab, India, and Dr. Sandeep Arora, Dean, Chitkara University, Rajpura, Punjab, India for support and institutional facilities.

\section{AUTHORS CONTRIBUTIONS}

All the authors have contributed equally

\section{CONFLICT OF INTERESTS}

The authors confirm that this article content has no conflict of interest.

\section{REFERENCES}

1. Harding SE, Davis SB, Deacon MP, Fiebrig I. Biopolymer mucoadhesives. Biotechnol Genet Eng Rev 1999;16:41-86.
2. Boddupalli BM, Mohammed ZN, Nath RA, Banji D. Mucoadhesive drug delivery system: an overview. J Adv Pharm Technol Res 2010;1:381-407.

3. Rao MR, Gaikwad SR, Shevate PM. Synthesis and characterization of a novel mucoadhesive derivative of psyllium seed polysaccharide. Int J Pharm Pharm Sci 2017:9:166-75.

4. Solaro R, Chiellini F, Battisti A. Targeted delivery of protein drugs by nanocarriers Materials 2010;3:1928-80.

5. Reddy PC, Chaitanya KS, Rao YM. A review on bioadhesive buccal drug delivery systems: current status of formulation and evaluation methods. DARU J Pharm Sci 2011;19:385-403.

6. Trivedi UM, Patel VM, Mahajan A, Mitesh P. A review on mucoadhesion, mucoadhesive polymer and mucoadhesive site. Int J Insti Pharm Life Sci 2011;1:1-8.

7. Alexander A, Sharma S, Khan MJ. Theories and factors affecting mucoadhesive drug delivery systems: a review. Int J Res Ayur Pharm 2011;2:1155-61.

8. Patel RS, Poddar SS. Development and characterization of mucoadhesive buccal patches of salbutamol sulphate. Curr Drug Delivery 2009;6:140-4.

9. Ponchel G, Touchard F, Duchene D, Peppas NA. Bioadhesive analysis of controlled-release systems I fracture and interpenetration analysis in poly (acrylic acid)-containing systems. J Controlled Release 1987;5:129-41.

10. Zhu Z, Zhai Y, Zhang N, Leng D, Ding P. The development of polycarbophil as a bioadhesive material in pharmacy. Asian J Pharm Sci 2013;8:218-27.

11. Chatterjee B, Amalina N, Sengupta P, Mandal UK. Mucoadhesive polymers and their mode of action: a recent update. J Appl Pharm 2017;7:195-203.

12. Anders R, Merkle HP. Evaluation of laminated muco-adhesive patches for buccal drug delivery. Int J Pharm 1989;49:231-40.

13. Sonawane M, Shinkar DR. Mucoadhesive buccal drug delivery system: review article. Int J Curr Pharm Sci 2017;9:1-14.

14. Saxena A, Tewari G, Saraf SA. Formulation and evaluation of mucoadhesive buccal patch of acyclovir utilizing inclusion phenomenon. Braz J Pharm Sci 2011;47:887-97.

15. Odeniyi MA, Atolagbe FM, Aina OO, Adetunji OA. Evaluation of mucoadhesive properties of native and modified starches of the root tubers of cocoyam (Xanthosoma sagittifolium). Afr J Biomed Res 2011;14:169-74.

16. Kaurav H, HariKumar SL, Kaur A. Mucoadhesive microspheres as carriers in drug delivery: a review. Int J Drug Dev Res 2012;4:21-34.

17. Menzel C, Hauser M, Frey A, Jelkmann M, Laffleur F, Gotzfried SK, et al. Covalently binding mucoadhesive polymers: Nhydroxysuccinimide grafted polyacrylates. Eur J Pharm Biopharm 2019;139:161-7.

18. Gandhi J, Sarkar I, Shah P, Naik H. A comprehensive review on buccal drug delivery system. J Pharm Sci 2019;8:20-32.

19. Samanthula KS, Satla SR, Bairi AG. Development, in vitro and ex-vivo evaluation of muco-adhesive buccal patches of candesartan cilexetil. Res J Pharm Technol 2019;12:3038-44.

20. Mangaraj S, Yadav A, Bal LM, Dash SK, Mahanti NK. Application of biodegradable polymers in food packaging industry: a comprehensive review. J Packag Technol Res 2019;3:77-96.

21. Andreeßen C, Steinbüchel A. Recent developments in nonbiodegradable biopolymers: precursors, production processes, and future perspectives. Appl. Microbiol Biotechnol 2019;103:143-57.

22. Sorushanova A, Delgado LM, Wu Z, Shologu N, Kshirsagar A, Raghunath $\mathrm{R}$, et al. The collagen suprafamily: from biosynthesis to advanced biomaterial development. Adv Mater 2019;31:1801651.

23. Rahman MA. Collagen of extracellular matrix from marine invertebrates and its medical applications. Mar Drugs 2019:17:118.

24. Abruzzo A, Bigucci F, Cerchiara T, Cruciani F, Vitali B, Luppi B. Mucoadhesive chitosan/gelatin films for buccal delivery of propranolol hydrochloride. Carbohydr Polym 2012;87:581-8.

25. Merzendorfer H, Cohen E. Chitin/Chitosan: versatile ecological, industrial, and biomedical applications. Extracellular Sugar Based Biopolymers Matrices; 2019. p. 541-624. 
26. Young S, Wong M, Tabata Y, Mikos AG. Gelatin as a delivery vehicle for the controlled release of bioactive molecules. J Controlled Release 2005;109:256-74.

27. Overby R, Feldman D. Influence of poly (Ethylene Glycol) end groups on poly (Ethylene Glycol)-albumin system properties as a potential degradable tissue scaffold. J Funct Biomater 2019;10:1.

28. Smart JD. Drug delivery using buccal-adhesive systems. Adv Drug Delivery Rev 1993;11:253-70.

29. Kragh Hansen U. Molecular aspects of ligand binding to serum albumin. Pharmacol Rev 1981;33:17-53.

30. Kumari A, Yadav SK, Yadav SC. Biodegradable polymeric nanoparticles based drug delivery systems. Colloids Surf B Biointerfaces 2010;75:1-8.

31. Mortazavi SA, Smart JD. An investigation into the role of water movement and mucus gel dehydration in mucoadhesion. J Controlled Release 1993;25:197-203.

32. Cid YP, Pedrazzi V, de Sousa VP, Pierre MB. In vitro characterization of chitosan gels for buccal delivery of celecoxib: influence of a penetration enhancer. AAPS PharmSciTech 2012;13:101-11.

33. Wurm F, Pham T, Bechtold T. Modelling of phase separation of alginate-carrageenan gels based on rheology. Food Hydrocoll 2019;89:765-72.

34. Agnihotri SA, Mallikarjuna NN, Aminabhavi TM. Recent advances on chitosan-based micro-and nanoparticles in drug delivery. J Controlled Release 2004;100:5-28.

35. Patel DP, Singh S. Chitosan: a multifacet polymer. Int J Curr Pharm Sci 2015;7:21-8.

36. Nayak AK, Ahmed SA, Tabish M, Hasnain MS. Natural polysaccharides in tissue engineering applications. Natural Polysaccharides in Drug Delivery and Biomedical Applications; 2019. p. 531-48.

37. Hacker MC, Krieghoff J, Mikos AG. Synthetic polymers. Principles Regenerative Medicine 2019:559-590.

38. Wang H, Wei X, Du Y, Wang D. Effect of water-soluble polymers on the performance of dust-suppression foams: Wettability, surface viscosity and stability. Colloid Surface A 2019;568:92-8.

39. Praveen C, Ujwala D. Synthesis and evaluation of water insoluble but swellable bioadhesive polymer for ocular drug delivery. Indian J Pharm Educ 2019;53:225-35.

40. Zavradashvili N, Sarisozen C, Titvinidze G, Otinashvili G, Kantaria T, Tugushi D, et al. Library of cationic polymers composed of polyamines and arginine as gene transfection agents. ACS Omega 2019;4:2090-101.

41. Cheng HN, Wyckoff W, Dowd MK, He Z. Evaluation of adhesion properties of blends of cottonseed protein and anionic watersoluble polymers. J Adhes Sci Technol 2019;33:66-78.

42. Khan M, Hassan MI, An X, Dai L, Li H, Khan A, et al. Chitosanbased polymer matrix for pharmaceutical excipients and drug delivery. Curr Med Chem 2019;26:2502-13.

43. Grewal P, Mundlia J, Ahuja M. Thiol modified moringa gum-a potential bioadhesive polymer. Carbohyd Polym 2019;209:400-8.

44. Teng L, Chen Y, Jin M, Jia Y, Wang Y, Ren L. Weak hydrogen bonds lead to self-healable and bioadhesive hybrid polymeric hydrogels with mineralization-active functions. Biomacromolecules 2018;19:1939-49.

45. Zahir Jouzdani F, Wolf JD, Atyabi F, Bernkop Schnürch A. In situ gelling and mucoadhesive polymers: why do they need each other? Expert Opin Drug Delivery 2018;15:1007-19.

46. Zhang Z, Liao M, Lou H, Hu Y, Sun X, Peng H. Conjugated polymers for flexible energy harvesting and storage. Adv Mater 2018;30:1704261.

47. Frank DS, Matzger AJ. Probing the interplay between amorphous solid dispersion stability and polymer functionality. Mol Pharm 2018;15:2714-20.

48. Baus RA, Zahir Jouzdani F, Dünnhaupt S, Atyabi F, Bernkop Schnürch A. Mucoadhesive hydrogels for buccal drug delivery: in vitro-in vivo correlation study. Eur J Pharm Biopharm 2019;142:498-505.

49. Ueda K, Iwai T, Sunazuka Y, Chen Z, Kato N, Higashi K, et al. Effect of molecular weight of hypromellose on mucin diffusion and oral absorption behavior of fenofibrate nanocrystal. Int J Pharm 2019;564:39-47.
50. Käsdorf BT, Weber F, Petrou G, Srivastava V, Crouzier T, Lieleg 0 . Mucin-inspired lubrication on hydrophobic surfaces. Biomacromolecules. 2017;18:2454-62.

51. Katsarov P, Pilicheva B, Uzunova Y, Gergov G, Kassarova M. Chemical cross-linking: A feasible approach to prolong doxylamine/pyridoxine release from spray-dried chitosan microspheres. Eur J Pharm Sci 2018;123:387-94.

52. Witten J, Samad T, Ribbeck K. Molecular characterization of mucus binding. Biomacromolecules 2019;20:1505-13.

53. Collado Gonzalez M, Gonzalez Espinosa Y, Goycoolea FM. Interaction between chitosan and mucin: fundamentals and applications. Biomimetics 2019;4:32.

54. Lamy B, Serrano DR, O'Connell P, Couet W, Marchand S, Healy $\mathrm{AM}$, et al. Use of leucine to improve aerodynamic properties of ciprofloxacin-loaded maltose microparticles for inhalation. Eur J Pharm Res 2019;1:2-11.

55. Dhote VK, Dhote K, Pandey SP, Shukla T, Maheshwari R, Mishra $\mathrm{DK}$, et al. Fundamentals of polymers science applied in pharmaceutical product development. Basic Fundamentals Drug Delivery 2019:85-112.

56. Narode MB, Sonawane KL, Khairnar RB, Dusad PP, Chalikwar SS. A review on buccal film: a modern expansion in drug delivery system. Asian J Biomaterial Res 2018;4:30-42.

57. Pawar PP, Ghorpade HS, Kokane BA. Sublingual route for systemic drug delivery. J Drug Delivery Ther 2018;8:340-3.

58. Zhao J, Wang J, Dang J, Zhu W, Chen Y, Zhang X, et al. A preclinical study-systemic evaluation of safety on mesenchymal stem cells derived from human gingiva tissue. Stem Cell Res Ther 2019;10:165.

59. Varshney S, Madhav S, Venkala N. Bio-flexy film formulation for delivery of tiagabine via oro trans-soft palatal route and its in vitro stability study approach. Asian J Nanosci Mater 2019;2:327-49.

60. Shirvan AR, Bashari A, Hemmatinejad N. New Insight into the fabrication of smart mucoadhesive buccal patches as a novel controlled-drug delivery system. Eur Polym J 2019;119:541-50.

61. Elad S, Zadik Y, Caton JG, Epstein JB. Oral mucosal changes associated with primary diseases in other body systems. Periodontol 2019;80:28-48.

62. Galili E, Zehavi EA, Zadik Y, Caspi T, Meltzer L, Merdler I, et al. Long-term scopolamine treatment and dental caries. Clin Oral Investig 2019;23:2339-44.

63. Singh B, Bala R, Gill NS. Mouth dissolving tablets: an innovative deviation in drug delivery system. Int J Pharm Sci Res 2019;11:1186-94.

64. Thakare EB, Malpure PS, Maru AD, More YM. Formulation and evaluation of mucoadhesive buccal tablet of repaglinide. J Drug Delivery Ther 2019;9:415-24.

65. Guo YG, Singh AP. Emerging technologies in buccal and sublingual drug administration. J Drug Delivery Sci Technol 2019;52:440-51

66. Teelavath M, Patnaik KR. Review on buccal adhesive drug delivery system: a promising strategy for poorly soluble drugs. J Drug Delivery Ther 2019;9:778-92.

67. Brown T, Petrovski S, Chan H, Angove M, Tucci J. Semi-solid and solid dosage forms for the delivery of phage therapy to epithelia. Pharmaceuticals 2018;11:26.

68. Ahmed EM, Ali S, Gaafar SM, Rashed LM, Fayed HL. Evaluation of topical human platelet lysate versus topical clobetasol in management of methotrexate-induced oral ulceration in rheumatoid arthritis patients: randomized-controlled clinical trial. Int Immunopharmacol 2019;73:389-94.

69. Vintiloiu A, Leroux JC. Organogels and their use in drug delivery-a review. J Controlled Release 2008;125:179-92.

70. Hebbar S, Dubey A, SRG, Mascarenhas SB. Studies on crosslinked chitosan hydrogel for matrix tablets of montelukast sodium. Int J Appl Pharm 2017;9:22-9.

71. Chaudhari PD, Desai US. Formulation and evaluation of niosomal in situ gel of prednisolone sodium phosphate for ocular drug delivery. Int J Appl Pharm 2019;11:97-116.

72. Otto W, Drahoslav L, Inventors. Process for producing shaped articles from three-dimensional hydrophilic high polymers. United States patent US 2,976,576; 1961.

73. Khanekar P, Momin M, Mhatre S. Application of 25 factorial design in optimization of superporous hydrogel synthesis 
containing natural mucilage. Int J Pharm Pharm Sci 2014;6:215-9.

74. Jaipakdee N, Pongjanyakul T, Limpongsa E. Preparation and characterization of poly (Vinyl Alcohol) Â€"Poly (Vinyl Pyrrolidone) mucoadhesive buccal patches for delivery of lidocaine HCL. Int J Appl Pharm 2018;10:115-23.

75. Roda A, Prabhu P, Dubey A. Design and evaluation of buccal patches containing combination of hydrochlorothiazide and atenolol. Int J Appl Pharm 2018;10:105-12.

76. Mondal N. The role of matrix tablet in drug delivery system. Int J Appl Pharm 2018;10:1-6.

77. Kamble S, Poul B, Udapurkar P. Bilayer tablet of tramadol and gabapentin for combination pharmacotherapy of neuropathic pain: development and characterization. Int J Appl Pharm 2018;10:100-7.

78. Kassem AA, Labib GS. Flash dissolving sublingual almotriptan malate lyotabs for management of migraine. Int J Pharm Pharm Sci 2016;9:125-31.

79. Albadry AA, Ali WK, Al-Saady FA. Formulation and evaluation of prochlorperazine maleate sustained release floating tablet. Int J Pharm Pharm Sci 2017;9:89-8.

80. Pandey S, Shah RR, Gupta A, Arul B. Design and evaluation of buccoadhesive controlled release formulations of prochlorperazine maleate. Int J Pharm Pharm Sci 2015;8:375-9.

81. Jhansi C, Harshini MYS, Sandeep K, Rao PC, Lakshmi CC. Comparision of efficacy and safety of oral labetalol and nifedipine in preeclampsia: a prospective observational study. Int J Pharm Pharm Sci 2015;7:277-80.

82. Maffei P, Borgia SL, Sforzini A, Bergamante V, Ceschel GC, Fini $A$, et al. Mucoadhesive tablets for buccal administration containing sodium nimesulide. Drug Delivery 2004;11:225-30.

83. Hassan N, Khar RK, Ali M, Ali J. Development and evaluation of buccal bioadhesive tablet of an anti-emetic agent ondansetron. AAPS PharmSciTech 2009;10:1085-92.

84. Parodi B, Russo E, Gatti P, Cafaggi S, Bignardi G. Development and in vitro evaluation of buccoadhesive tablets using a new model substrate for bioadhesion measures: the eggshell membrane. Drug Dev Ind Pharm 1999;25:289-95.

85. Parviez N, Ahuja A, Khar RK. Development and evaluation of muco-adhesive buccal tablets of lignocaine hydrochloride. Ind J Pharm Sci 2002;64:563-7.

86. Tsutsumi K, Obata Y, Nagai T, Loftsson T, Takayama K. Buccal absorption of ergotamine tartrate using the bioadhesive tablet system in guinea-pigs. Int J Pharm 2002;238:161-70.

87. Tiwari D, Goldman D, Town C, Sause R, Madan PL. In vitro-in vivo evaluation of a controlled release buccal bioadhesive device for oral drug delivery. Pharm Res 1999;16:1775-80.

88. Tiwari D, Sause R, Madan PL, Goldman D. Evaluation of polyoxyethylene homopolymers for buccal bioadhesive drug delivery device formulations. AAPS Pharm Sci 1999;1:50-7.

89. Umarji B, Patil R, Birajdar R, Mysore S, Bilagi S, Audurti D. Formulation and in vitro evaluation of mucoadhesive buccal tablets of furosemide. World J Pharm Pharm Sci 2012;1:1041-63.

90. Miyazaki S, Nakayama A, Oda M, Takada M, Attwood D. Chitosan and sodium alginate based bioadhesive tablets for intraoral drug delivery. Bio Pharm Bull 1994;17:745-7.

91. Kuipers ME, Heegsma J, Bakker HI, Meijer DK, Swart PJ, Frijlink $\mathrm{EW}$, et al. Design and fungicidal activity of mucoadhesive lactoferrin tablets for the treatment of oropharyngeal candidosis. Drug Delivery 2002;9:31-8.

92. Choi HG, Kim CK. Development of omeprazole buccal adhesive tablets with stability enhancement in human saliva. J Controlled Release 2000;68:397-404.

93. Alur HH, Beal JD, Pather SI, Mitra AK, Johnston TP. Evaluation of a novel, natural oligosaccharide gum as a sustained-release and mucoadhesive component of calcitonin buccal tablets. J Pharm Sci 1999;88:1313-9.

94. Patel VM, Prajapati BG, Patel MM. Formulation, evaluation, and comparison of bilayered and multilayered mucoadhesive buccal devices of propranolol hydrochloride. AAPS PharmSciTech 2007;8:E147-54.

95. Shidhaye SS, Thakkar PV, Dand NM, Kadam VJ. Buccal drug delivery of pravastatin sodium. AAPS PharmSciTech 2010;11:416-24.
96. Zhao SP, Zhang LM, Ma D. Supramolecular hydrogels induced rapidly by inclusion complexation of poly ( $\varepsilon$-caprolactone) poly (ethylene glycol) poly ( $\varepsilon$-caprolactone) block copolymers with $\alpha$-cyclodextrin in aqueous solutions. J Phys Chem B 2006;110:12225-9.

97. Velmurugan S, Deepika B, Nagaraju K, Vinushitha S. Formulation and in vitro evaluation of buccal tablets of piroxicam. Int J Pharm Tech Res 2010;2:1958-68.

98. Anlar S, Capan Y, Guven O, Gogus A, Dalkara T, Hincal A. Formulation and in vitro-in vivo evaluation of buccoadhesive morphine sulfate tablets. Pharm Res 1994;11:231-6.

99. Garcia Gonzalez N, Anguiano Igea S, Delgado Charro B, Otero Espinar FJ, Blanco Mendez J. In vitro characterization of bioadhesive metoclopramide tablets for buccal application prepared with polyacrylic acid and hydroxypropyl methylcellulose. STP Pharm Sci 1992;2:494-9.

100. Voorspoels J, Remon JP, Eechaute W, De Sy W. Buccal absorption of testosterone and its esters using a bioadhesive tablet in dogs. Pharm Res 1996;13:1228-32.

101. Chai Q, Jiao Y, Yu X. Hydrogels for biomedical applications: their characteristics and the mechanisms behind them. Gels 2017;3:1-15.

102. Takeuchi H, Yamamoto H, Kawashima Y. Mucoadhesive nanoparticulate systems for peptide drug delivery. Adv Drug Delivery Rev 2001;47:39-54.

103. Sakata O, Onishi H, Machida Y. Development of semisolid dosage form of clonazepam for oral cavity administration. Yakugaku Zasshi: J Pharm Soc Japan 2010;130:119-25.

104. Richards W, Platzker A, Church JA, Yamamoto F, Foster S. Steroiddependent asthma treated with inhaled beclomethasone dipropionate in children. Ann Allergy 1978;41:274-7.

105. Kilor V, Sapkal N, Daud A, Humne S, Gupta T. Development of stable nanosuspension loaded oral films of glimepiride with improved bioavailability. Int J Appl Pharm 2017;9:28-3.

106. Tamer MA, Hammid SNA Al, Ahmed B. Formulation and in vitro evaluation of bromocriptine mesylate as fast dissolving oral film. Int J Appl Pharm 2018;10:7-20.

107. Dey P, Ghosh A. Wafers: An Innovative Advancement of OroDispersible Films. Int J App Pharm 2016;8:1-7.

108. Speer I, Preis M, Breitkreutz J. Novel Dissolution Method for Oral Film Preparations with Modified Release Properties. AAPS PharmSciTech. 2019;20:1-15.

109. Karki S, Kim H, Na SJ, Shin D, Jo K, Lee J. Thin films as an emerging platform for drug delivery. Asian J Pharm Sci 2016;11:559-574.

110. Irfan M, Rabel S, Bukhtar Q, Qadir MI, Jabeen F, Khan A. Orally disintegrating films: a modern expansion in drug delivery system. Saudi Pharm J 2016;24:537-546.

111. Averineni RK, Sunderajan SG, Mutalik S, Nayak U, Shavi G, Armugam K, Meka SR, Pandey S, Nayanabhirama U. Development of mucoadhesive buccal films for the treatment of oral sub-mucous fibrosis: a preliminary study. Pharm Dev Techol 2009;14:199-207.

112. Sabry SA. Sodium cromoglycate mucoadhesive buccal patches: design, fabrication, in vitro and in vivo characterization. Int J Appl Pharm 2018;10:76-2.

113. Sadeq ZA, Rajab NA. Studying the effect of different variables on the formulation of mucoadhesive buccal patches of captopril. Int J Appl Pharm 2017;9:16-1.

114. Danjo K, Kitamura Y, Miyagawa Y, Otsuka A. Release of isosorbide dinitrate from polymer film dosage forms and absorption of this drug through the oral mucosa of rats. Chem Pharm Bull 1994;42:2126-30.

115. Okamoto H, Nakamori $\mathrm{T}$, Arakawa $\mathrm{Y}$, Iida $\mathrm{K}$, Danjo $\mathrm{K}$. Development of polymer film dosage forms of lidocaine for buccal administration: II comparison of preparation methods. J Pharm Sci 2002;91:2424-32.

116. Save T, Shah MU, Ghamande AR, Venkitachalam P. Comparative study of buccoadhesive formulations and sublingual capsules of nifedipine. J Pharm Pharmcol 1994;46:192-5.

117. Patel MP, Bharadia PD, Chhabria MT. A systemic review on buccal drug delivery systems. Mater Res Lett 2018;11:26.

118. Anders R, Merkle HP. Evaluation of laminated muco-adhesive patches for buccal drug delivery. Int J Pharm 1989;49:231-40. 
119. Oguchi M, Shikama N, Sasaki S, Gomi K, Katsuyama Y, Ohta S, et al. Mucosa-adhesive water-soluble polymer film for treatment of acute radiation-induced oral mucositis. Int J Radiat Oncol Biol Phys 1998;15:1033-7.

120. Minabe M, Takeuchi K, Tomomatsu E, Hori T, Umemoto $T$. Clinical effects of local application of collagen film-immobilized tetracycline. J Clin Periodontol 1989;16:291-4.

121. Kim DW, Kim YI, Han HH, Cho KH, Kim JO, Yong CS, et al. Development of a novel triamcinolone acetonide-loaded spray solution for the treatment of stomatitis. Int J Pharm Sci 2014;69:512-7.

122. Ritschel WA, Ritschel GB, Forusz H, Kraeling M. Buccal absorption of insulin in the dog. Res Commun Chem Pathol Pharmacol 1989;63:53-67.
123. Ilango R, Kavimani S, Mullaicharam AR, Jayakar B. In vitro studies on buccal strips of glibenclamide using chitosan. Indian J Pharm Sci 1997;59:232-5.

124. Wathoni N, Hasanah AN, Mohammed AFA, Pratiwi ED, Mahmudah R. Accelerated wound healing ability of sacran hydrogel film by keratinocyte growth factor in alloxan-induced diabetic mice. Int J Appl Pharm 2018;10:57-61.

125. Reddy BHN, Rauta PR, Lakshmi VV, Sreenivasa S. Development formulation, and evaluation of sodium alginate-g-poly (Acryl Amide-Co-Acrylic Acid/Cloiste-30b)/Agnps hydrogel composites and their applications in paclitaxel drug delivery and anticancer activity. Int J Appl Pharm 2018;10:141-50.

126. Yadav SK, Mishra MK, Tiwari A, Shukla A. Emulgel: a new approach for enhanced topical drug delivery. Int J Curr Pharm Sci 2016;9:15-9. 